Implications of the Temporal Distribution of High-Mg Magmas for Mantle Plume Volcanism through Time

Author(s): Ann E. Isley and Dallas H. Abbott

Source: The Journal of Geology, Vol. 110, No. 2 (March 2002), pp. 141-158

Published by: University of Chicago Press

Stable URL: http://www.jstor.org/stable/10.1086/338553

Accessed: 22-01-2016 15:05 UTC

Your use of the JSTOR archive indicates your acceptance of the Terms \& Conditions of Use, available at http://www.jstor.org/page/ info/about/policies/terms.jsp

JSTOR is a not-for-profit service that helps scholars, researchers, and students discover, use, and build upon a wide range of content in a trusted digital archive. We use information technology and tools to increase productivity and facilitate new forms of scholarship. For more information about JSTOR, please contact support@jstor.org. 


\title{
Implications of the Temporal Distribution of High-Mg Magmas for Mantle Plume Volcanism through Time
}

\author{
Ann E. Isley and Dallas H. Abbott ${ }^{1}$ \\ Department of Earth Sciences, Oswego State University of New York, Oswego, New York 13126, U.S.A. \\ (e-mail: isley@Oswego.edu)
}

\begin{abstract}
A B S T R A C T
We compile a 3.7-b.yr.-long time series of ultramafic and mafic rocks including extrusives and shallow intrusives (dikes and sills). We infer that peaks in the time series represent mantle plume events. Rocks erupted from plumes are becoming more Ti rich through time, and several rock types having $>18 \mathrm{wt} \% \mathrm{MgO}$ are Phanerozoic analogs for komatiites. These include meimechites, ankaramites, and rocks previously called "picrites." Spectral analysis reveals the time series is driven by periods of $\sim 800$ and $\sim 273$ m.yr. Two 256-m.yr.-long data subsets, one sampling the Archean and one sampling the Phanerozoic, are driven by periods of $26 \pm 3$ and $34.5 \pm 4.5 \mathrm{~m}$.yr., respectively. The $\sim 800$-m.yr.long energy may reflect changes in the rate of impacts of extraterrestrial objects, tectonic slab cascades into the mesosphere, or resonance between free-core nutations and those forced by solar torques. We suggest that the 273 m.yr. period reflects the cosmic year. The latter modulates fluctuation in cometary impacts that occur with a 30-35 m.yr. period (Matese et al. 1996). Thus, there may be more than one driving force for mantle plume volcanism, including forces endogenic and exogenic to Earth.
\end{abstract}

\section{Introduction}

In a recent article, we discussed the temporal distribution of Archean and Paleoproterozoic mafic and ultramafic igneous events and inferred that episodes of substantially increased basic magmatism reflect mantle plume volcanism (Isley and Abbott 1999|. Since that work, we have compiled a data set of the ages of high-Mg volcanic units and high$\mathrm{Mg}$ dikes and sills spanning more than $3.7 \mathrm{Ga}$ of Earth history. (For brevity's sake, this data set has been included in The Journal of Geology's data depository.) In this article, we analyze the time series to evaluate secular changes in the chemistry of high-Mg lavas and to determine whether there are well-defined periodicites in the data set. This work may provide insights into the forces that ultimately drive mantle plume events.

In our previous work, we investigated four proxies of mantle plume activity: komatiites, continental flood basalts, mafic dikes, and layered (ultra)mafic intrusions (Isley and Abbott 1999). Komatiites proved particularly robust proxies of 2001 .

Manuscript received October 31, 2000; accepted August 14,

${ }^{1}$ Lamont-Doherty Earth Observatory of Columbia University, Palisades, New York 10964, U.S.A. mantle plume events because they capture both continental and putative oceanic flood basalt sequences. Although they were once thought to be typical of Archean mid-ocean ridge crust, komatiites actually had sources a few to several $100^{\circ} \mathrm{C}$ hotter than the average mantle, even in the Archean (Abbott et al. 1994; Puchtel et al. 1998b; therefore, even Precambrian komatiites are now generally acknowledged as expressions of mantle plume volcanism (Campbell et al. 1989; Campbell and Griffiths 1990). However, the degree to which all komatiites reflect high mantle temperatures is debatable since komatiites could have formed by melting of a hydrous mantle with temperatures only $150^{\circ} \mathrm{C}$ higher at the top of the asthenosphere than at present (Gromshei et al. 1990). Some have argued that komatiites are not necessarily the products of mantle plumes (Burke 1997; De Wit 1998). However, the lack of both degassing structures and porphyritic textures in most komatiites and their chemical and isotopic signatures led Arndt et al. (1998) to conclude that, although some rare komatiites were hydrous, most were not. We concur and maintain that, while komatiites may not be 
perfect recorders of mantle plume activity, they are among the most robust indicators available.

We found other proxies of mantle plume activity less dynamic (Isley and Abbott 1999). For example, mantle plume events promote mafic dike swarms, but not all mafic dike swarms are the result of mantle plume volcanism nor are all layered igneous intrusions necessarily the result of mantle plume volcanism. It may be necessary to cull these data sets to obtain clear signals of mantle plume activity. Ernst and Buchan (1997), for example, drew inferences about plumes by focusing only on giant radiating dike swarms.

Here, we focus on the geologic record of high-Mg lavas, including komatiites. Most komatiites erupted before the beginning of the Mesoproterozoic $(1.6 \mathrm{Ga})$. Assessing mantle plume activity from the Mesoproterozoic onward requires a proxy or proxies in addition to komatiites. Several other lithologies are as rich in $\mathrm{MgO}$ as komatiites (e.g., meimechites). Because the ratios $\mathrm{Mg} / \mathrm{Si}$ and $\mathrm{Fe} / \mathrm{Si}$ increase in mafic volcanics as a function of either melt-source temperature or degree of melting (which may also reflect mantle temperature), we include other high-Mg rocks in the data set.

\section{Data Set Description}

The Lithologies. The International Union of Geological Sciences (IUGS) recently reclassified highMg rocks (Le Bas 2000). Previously, rocks having $>18$ wt \% MgO were called "picrites," "ferropicrites," "ankaramites," "komatiites," or "meimechites" (using the IUGS recommendations for nomenclature from 1989 and earlier). Rocks with $>18$ wt $\% \mathrm{MgO}$ and $\mathrm{Na}_{2} \mathrm{O}+\mathrm{K}_{2} \mathrm{O}$ of $1-2$ wt $\%$ were called "picrites." If such rocks were enriched in $\mathrm{Fe}$, they were called "ferropicrites" (Gibson et al. 2000). Ankaramites were a subset of picrites rich in titanian augite. Rocks less alkaline than picrites were termed "komatiites" or "meimechites." Komatiites had $<1$ wt $\% \mathrm{TiO}_{2}$, while meimechites were richer in $\mathrm{TiO}_{2}$. There is a host of lithologies that are compositionally analogous to mixtures of komatiitic, (ferro/picritic, and/or basaltic magmas. Such rocks include picritic komatiite, basaltic komatiite, komatiitic basalt, picritic basalt, and highMg basalt. The data set includes such mixtures, and a few of these sequences have units with $\mathrm{MgO}$ between 10 and $14 \mathrm{wt} \%$. All of these units had geochemistries indicative of the dilution of a komatiitic or picritic melt, by incorporation of subcontinental lithosphere or crustal contamination, as described by Lightfoot et al. (1991), Riganti and Wilson (1995), Fedorenko et al. (1996), Stone and Stone
(2000), and modeled by Sparks (1986) and Jellinek and Kerr (1999). Rocks with $\mathrm{MgO}$ of 10-14 wt \% whose geochemistries did not dictate admixture of a high-Mg melt with another source were excluded from the data set.

Rocks referred to in this work are described using the 1989 IUGS classification so that we use the same term that was applied to rocks in the original studies we cite. We note that the rocks we refer to here as "komatiite" and "meimechite" retain that nomenclature in the recent IUGS reclassification (Le Bas 2000). However, some of the rocks that were previously termed "basaltic komatiite," "komatiitic basalt," "picritic basalt," and "high-Mg basalt" might now be called "picrite." Rocks having $>18$ wt $\% \mathrm{MgO}$ and $1-2$ wt $\% \mathrm{Na}_{2} \mathrm{O}+\mathrm{K}_{2} \mathrm{O}$, previously labeled picrites, would now be referred to as "meimechites" (Le Bas 2000).

There are several examples of Phanerozoic komatiites in the data set. There is a long-standing conviction that the only Phanerozoic komatiites are those of Gorgona Island (e.g., Kerr et al. 1996). However, several other sequences have units with an $\mathrm{MgO}$ component consistent with komatiitic chemistry. Spinifex texture has been reported for most of these sequences (Buturlinov and Kisil' 1985; Paraskevopoulos and Economou 1986; Struyeva 1988; Spadea et al. 1989; Fang and Ma 1994; Alvarado et al. 1997).

Many ankaramites from the pre-Cenozoic record have been interpreted as island arc volcanics. These ankaramites all are associated with calc-alkaline volcanic sequences. Cenozoic ankaramites comprise some of the volcanic units in the Lesser Antilles, Indonesian, Vanuata, and Izu-Bonin arcs (Hawkesworth et al. 1979; Maillet 1982; Foden 1983; Fukuyama 1983). However, there are many more examples of Cenozoic ankaramites associated with hotspots and mantle plumes (Isley and Abbott 2000). For example, ankaramites contribute to the volcanic extrusives erupting from $>20$ hotspots, including the Jan Mayan, Icelandic, Azores, Trindade, Society, Samoan, and Hawaiian hotspots (Johnson et al. 1986; Kennedy et al. 1991; Pegram and Allegre 1992; Stecher 1998; Guest et al. 1999; Fodor and Hanan 2000). In this work, we assume that all volcanic sequences containing ankaramites but lacking dominant associations with calc-alkaline rocks erupted in response to hotspot or mantle plume activity.

Haggerty (1994) used other rare igneous rocks to identify Phanerozoic mantle plume events, including kimberlites, lamproites, and carbonatites. These alkaline rocks are erupted only in continen- 
tal settings, however, and therefore would not track mantle plumes arriving under oceanic lithosphere.

The Data Set. $\quad$ Our literature search revealed 124 examples of dated, high-Mg igneous rocks. About $85 \%$ of the units are volcanic. Archean volcanics typically occur in greenstone belts, and high-Mg lavas in these generally contribute only a fraction of the volume of extrusive rocks (Francis and Hynes 1979). Similarly, flood basalt sequences are generally dominated by tholeiitic lavas but can contain individual high-Mg units. For example, the ca. 2.7Ga Ventersdorp Supergroup consists mainly of tholeiitic basalt. Individual units within the Ventersdorp (particularly those of the Klipriviersburg Group) are unusually Mg rich (Winter 1976; Keyser 1998). Similarly, the Permo-Triassic Siberian Flood Traps are dominantly tholeiitic but also contain meimechitic units with as much as $38 \mathrm{wt} \% \mathrm{MgO}$ (Fedorenko and Czamenske 1997).

About $15 \%$ of the units in the data set are shallow intrusive rocks with a high-Mg chemistry. Some of the largest probably acted as feeders to flood basalts that have since been eroded. Other dike systems are smaller, and their areal extent does not dictate that they fed widespread flood basalts. Nonetheless, their extrusive equivalents certainly would have met our geochemical criterion of having $>10 \mathrm{wt} \% \mathrm{MgO}$ (e.g., extrusions erupting from the 2.42-Ga picritic Scourie Dike Swarm; other Scourie dikes are not picritic and would not meet this criterion; Heaman and Tarney 1989).

The Age Data. The age data presented for volcanics in greenstone belts or flood basalt sequences were most often achieved by $\mathrm{U} / \mathrm{Pb}$ analysis of zircon or baddelyite from felsic units. This approach produces results having high degrees of precision so that ages can be limited confidently to periods
$<20$ m.yr. long. The felsic units that have been chosen for radiochronologic work typically occur interlayered with more mafic flows in a single flood basalt sequence. By convention, therefore, ages for felsic units are taken to be the ages of all rocks in a thick volcanic sequence. That assumption is bolstered by how quickly Phanerozoic flood basalts erupted (White and McKenzie 1995). For example, about $90 \%$ of the Siberian Flood Traps erupted in $<5$ m.yr. (Basu 1995; Sharma 1997; Venkatesan et al. 1997). The bulk of the Deccan Traps erupted in $<10$ m.yr., as did the Parana-Etendeka flood basalts (Turner et al. 1994; Peng and Mahoney 1995; Bhattacharji et al. 1996). The $2 \times 10^{6} \mathrm{~km}^{3}$ Shatsky Rise was built in a million years or less (Sager and Han 1993).

Geochronologic analyses of (ultra)mafic rocks, as by the Sm-Nd method, generally do not produce age results that are as well defined. Sequences are rarely constrained to a period of time $<50 \mathrm{~m}$.yr. long. Even poorer constraints may occur if the age of a volcanic sequence is evaluated by assessing the geochronologies of underlying and intruding (usually felsic) sequences, regardless of the technique used, or by extrapolation from biostratigraphic data.

Age dates achieved through geochronologic means are reported as an age or ages, each plus or minus its standard deviation. We consider the maximum age of the age range for a single sequence to be the oldest reported age minus its standard deviation and the minimum age to be the youngest reported age plus its standard deviation. Some Phanerozoic sequences were constrained to a portion of geologic time by biostratigraphic means. Of the units in the data set, $53 \%$ have ages bracketed by

Table 1. High-Mg Lavas in Time Periods ca. 800 m.yr. Long

\begin{tabular}{|c|c|c|c|c|c|}
\hline & $4.0-3.2 \mathrm{Ga}$ & $3.2-2.4 \mathrm{Ga}$ & $2.4-1.6 \mathrm{Ga}$ & $1.6-0.8 \mathrm{Ga}$ & $0.8 \mathrm{Ga}-55 \mathrm{Ma}$ \\
\hline \multicolumn{6}{|l|}{ Total events: } \\
\hline Sequences in age range & 15 & 40 & 20 & 5 & 44 \\
\hline $\begin{array}{l}\text { Types of high-Mg } \\
\text { rocks in all }\end{array}$ & & & & & \\
\hline sequences & 20 & 43 & 23 & 5 & 62 \\
\hline \multicolumn{6}{|l|}{ Lava type: } \\
\hline Komatiite & $9(45.0)$ & $30(69.8)$ & $10(43.5)$ & $1(20)$ & $6(9.7)$ \\
\hline Picritic komatiite & $0(0)$ & $1(2.3)$ & $0(0)$ & $0(0)$ & $0(0)$ \\
\hline Ferropicrite & $0(0)$ & $2(4.7)$ & $1(4.3)$ & $0(0)$ & $3(4.8)$ \\
\hline Picrite & $1(5)$ & $2(4.7)$ & $1(4.3)$ & $3(60)$ & $37(59.7)$ \\
\hline Basaltic komatiite & $1(5)$ & $2(4.7)$ & $0(0)$ & $0(0)$ & $0(0)$ \\
\hline Komatiitic basalt & $5(25.0)$ & $3(7)$ & $7(30.4)$ & $0(0)$ & $1(1.6)$ \\
\hline Picritic basalt & $0(0)$ & $0(0)$ & $0(0)$ & $0(0)$ & $1(1.6)$ \\
\hline High-Mg basalt & $4(20.0)$ & $3(7.0)$ & $4(17.4)$ & $0(0)$ & $0(0)$ \\
\hline Meymechite & $0(0)$ & $0(0)$ & $0(0)$ & $0(0)$ & $3(4.8)$ \\
\hline Ankaramite & $0(0)$ & $0(0)$ & $0(0)$ & $1(20)$ & $11(17.7)$ \\
\hline
\end{tabular}

Note. Data in parentheses are percentages. 
periods shorter than 20 m.yr. The ages of $37 \%$ of the units are constrained to periods $20-100 \mathrm{~m}$.yr. long. Only $10 \%$ of the sequences have ages whose uncertainty exceeds 100 m.yr.

\section{Methods}

To examine qualitative changes in the absolute and relative importance of different sorts of high-Mg lithologies through time, we divide the data set into time periods of approximately $800 \mathrm{~m}$.yr. length (table 1). In some cases, more than one high-Mg lithology contributes to the individual sequences comprising the data set. For these sequences, each lithology is entered individually in table 1 .

The time series was generated by adding together Gaussian (normal) distributions of area 1 and width $1 \sigma$, where $1 \sigma$ represents $1 \mathrm{SD}$ about the mean age (Isley and Abbott 1999; fig. 1). We assume that the $1 \sigma$ error of the age is the error given by those who determined the age. (Because most published errors of $\mathrm{U} / \mathrm{Pb}$ ages are $2 \sigma$ errors, this is a conservative estimate of the error in ages.)

Qualitatively, a peak's height reflects the number of sequences with overlapping ages contributing to it and the narrowness of each sequence's age range. A single sequence with very narrow age constraints can produce a peak. Therefore, interpreting an individual peak as indicative of mantle plume volcanism should be done cautiously, and our confidence in such an interpretation obviously rises with the number of high-Mg rock sequences contributing to it. In figure 1, only three peaks having heights $>0.10$ are constrained by a single age date. These are at 3515, 3406, and $2235 \mathrm{Ma}$. Otherwise, peaks falling between 0.10 and 0.15 reflect overlap of at least two sequences' ages, and peaks higher than 0.20 reflect overlap of three to eight sequences' ages.

We used the program Matlab to calculate a spectrum. Before processing for its spectral content, the time series data were detrended and processed with a Hanning window (cosine taper). This procedure reduced the amount of spurious long-period noise in our results. We found in the literature that there were varying estimates of the amount of error permitted in the data before a spectral peak could not be resolved with confidence. We used the most conservative estimate, that of Heisler and Tremaine (1989), that the mean root-mean-square error of the data must be $13 \%$ or less of the period that is being analyzed. This means that, in order to resolve a periodicity of $26 \mathrm{~m}$.yr., the mean $\mathrm{rms}$ error of the ages cannot exceed 3.3 Ma. In practice, we found that the maximum age errors in our data sets fitting

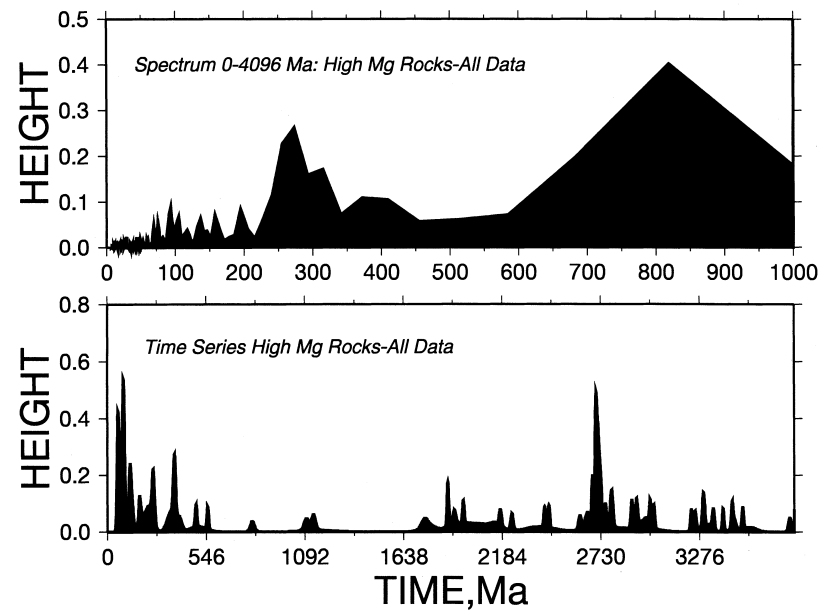

Figure 1. Top, spectrum of entire data set. Note that the age of errors of the data set mean that only spectral peaks of $140 \mathrm{~m}$.yr. and higher are statistically significant. Bottom, time series of entire data set. Peak height is proportional to age error and the number of events. Tick spacing is at $273 \mathrm{~m}$.yr., the dominant spectral period. Note that both the Phanerozoic and Archean parts of the data set appear to have portions with a 273-m.yr. periodicity.

this criteria ranged from 6 to $7.5 \mathrm{~m}$.yr. We found two parts of the complete data set had enough ages with low errors to permit a search for such periods, a Phanerozoic data set with ages ranging between 256 and $0 \mathrm{Ma}$, and an Archean data set with ages ranging between 2856 and $2600 \mathrm{Ma}$. The mean rms error of the entire data set is $18.2 \mathrm{~m}$.yr., low enough to resolve spectral periods of $140 \mathrm{~m}$.yr. and higher. Results of the spectral analyses are presented in figures $1-3$ and table 2.

\section{Results}

Lithologic Trends through Time. Although the total number of high-Mg events recorded through time does not vary monotonically, there are discernible temporal trends in different types of high$\mathrm{Mg}$ lavas. For example, the earliest volcanic sequences do not unequivocally contain komatiites. These include presumably volcanic units in the Isua and Nulliak Supracrustal sequences, the Talga Talga subgroup, the Dwalile greenstone belt, and the Coonterunah Succession (Hamilton et al. 1981; Kröner and Tegtmeyer 1994; Buick et al. 1995). The Nulliak, for example, contains amphibolites with broad compositional affinities to komatiitic basalts (Nutman et al. 1989). This appears to extend to other units we have not been able to include in our 

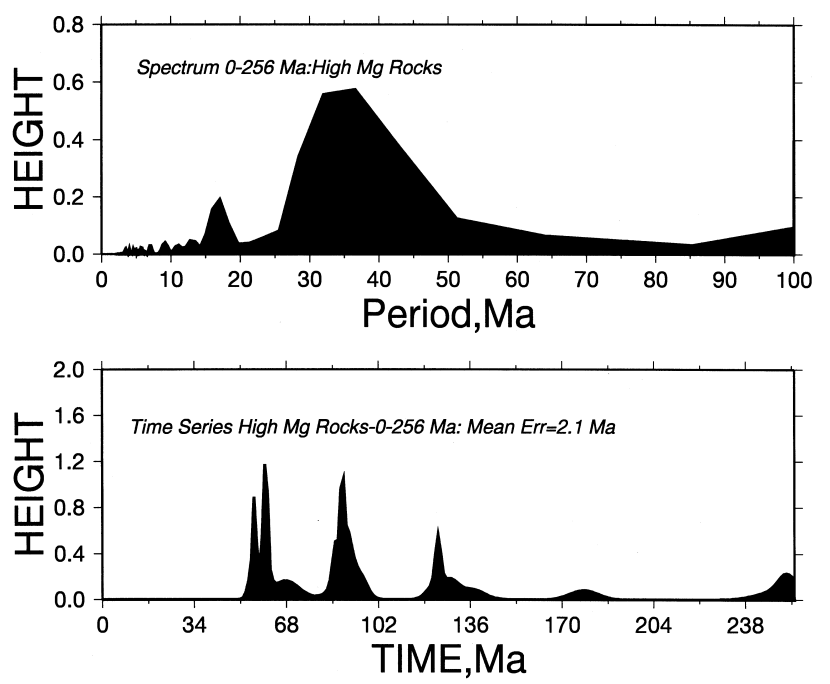

Figure 2. Top, spectrum of 256-0 Ma data subset with age errors $\leq 7.5 \mathrm{Ma}$ ( 22 out of 32 data points in that time interval). Note that such age errors mean that only spectral peaks of $26 \mathrm{~m}$.yr. and higher are statistically significant. Bottom, time series of 256-0 Ma part of the data set used to perform the spectral analysis. Peak height is proportional to age error and the number of events. Tick labels are every $34 \mathrm{~m}$.yr., the dominant spectral period. Note that the $\sim 34-m$.yr. periodicity shows up particularly well in the youngest part of the data set, which has peaks that are defined by three to eight sequences' ages at 124 , 89 , and 60/56 Ma. (See also table 3 in the text.)

data set because their ages are not well constrained. For example, although the age of the Akilia Assemblage of Greenland has not been clearly documented, it is undoubtedly of Early Archean age (Schiotte et al. 1989). It contains metamorphosed ultramafic rocks whose precursors cannot be defined unequivocally as komatiites (Nutman et al. 1996).

Komatiites became the most common type of high-Mg eruption after $3.5 \mathrm{Ga}$ and continue to comprise the largest percentage of recorded high-Mg lavas through 1.6 Ga (table 1). Several other lithologies (basaltic komatiites, komatiitic basalts, and high-Mg basalts) are virtually limited to sequences older than 1.6 Ga.

Most komatiites are located in greenstone belt or flood basalt sequences. As we emphasized above, komatiites found in either of these settings are usually interbedded with more voluminous tholeiitic basalts. For example, the Archean Klipriviersburg Group (Ventersdorp Supergroup) is a flood basalt sequence containing komatiites (Nelson et al. 1992).

Komatiites are found less commonly in other as- sociations. For example, in a ca. $<30$-m.yr. period from 2.72 to $2.69 \mathrm{Ga}$, komatiitic eruptions produced thick, laterally extensive units including the Empire Flow, the Deloro Formation, the Reliance Formation, and the "lava river" recorded in the Eastern Goldfields Province of the Yilgarn craton. Even volcaniclastic komatiites are known, including those of the Outokompu Assemblage (Saverikko 1990). Although their ages are not well constrained, these units and the ferropicritic tuffs of Pechenga (Hanski 1992) may be geologically contemporaneous at ca. $2.0 \mathrm{Ga}$.

Picrites become more common through time. The earliest ferropicrite is the 45-115-m-thick, 2.72-Ga Boston Creek Flow (Stone et al. 1987). The earliest unequivocally picritic sequences were erupted in the Strelna Group (2447.6-2438 Ma; Amelin et al. 1995), with roughly contemporaneous emplacement of the picritic Scourie Dikes (2425-2414 Ma; Heaman and Tarney 1989). Picrites comprise almost $60 \%$ of all high-Mg lavas with an age younger than $0.8 \mathrm{Ga}$.

In the earliest time periods, the most alkaline lavas are unknown (table 1). The oldest ankara-
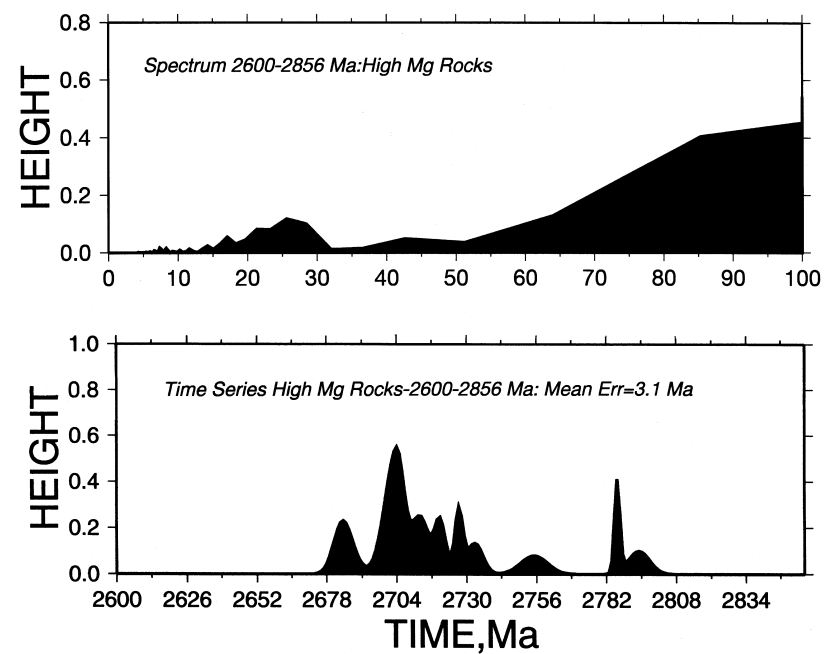

Figure 3. Top, spectrum of 2856-2600 Ma data subset with age errors $\leq 6 \mathrm{~m}$.yr. (15 out of 26 data points in that time interval). Note that the age errors mean that only spectral peaks of $26 \mathrm{~m}$.yr. and higher are statistically significant. Bottom, time series of 2856-2600 Ma part of the data set used to perform the spectral analysis. Peak height is proportional to age error and the numbers of events. Tick labels are every $26 \mathrm{~m}$.yr., the dominant spectral period. Note that the $\sim 26-\mathrm{m}$.yr. periodicity shows up particularly well in the Middle Archean, which has peaks that are defined by two to six sequences' ages at 2786 , 2755, 2727, and $2704 \mathrm{Ma}$. 
Table 2. Significant Spectral Energy, Time Series of High-Mg Magmatism

\begin{tabular}{lccc}
\hline & \multicolumn{3}{c}{$\begin{array}{c}\text { Peak height in time } \\
\text { series age range (Ma) }\end{array}$} \\
\cline { 2 - 4 } Period (m.yr.) & $4096-0$ & $2856-2600$ & $256-0$ \\
\hline $819+204 /-137$ & .401 & $\ldots$ & $\ldots$ \\
$273+19 /-16$ & .261 & $\ldots$ & $\ldots$ \\
$256+17 /-16$ & .227 & $\ldots$ & $\ldots$ \\
$36.6 \pm 6$ & $\ldots$ & $\ldots$ & .573 \\
$32 \pm 4$ & $\ldots$ & $\ldots$ & .557 \\
$28.4 \pm 4$ & $\ldots$ & .100 & $\ldots$ \\
$25.6 \pm 2$ & $\ldots$ & .118 & $\ldots$ \\
\hline
\end{tabular}

mites erupted about $800 \mathrm{Ma}$, and the oldest meimechites are about 400 m.yr. old. Although rare, meimechites contribute to the Siberian Traps (Fedorenko and Czamenske 1997), West Siberia (Goncharenko et al. 1981), and Neogene-Quaternary sequences (Gibson et al. 2000).

Spectral Analysis. The strongest periodicity influencing the 4096-0 m.yr. time series is $819+204 /$ -137 m.yr. (table 2). Also contributing a significant amount of energy to the spectrum is a period peaking at about $273 \mathrm{~m}$.yr. (fig. 1). The 256-0 m.yr. time series was dominated by a $34.5 \pm 4.5 \mathrm{~m}$.yr. period. Spectral energy peaked at a period of $26 \pm 3 \mathrm{~m}$.yr. in the 2856-2600 m.yr. time series. (see figs. 2, 3; table 2.)

\section{Do High-Mg Extrusives Capture All Mantle Plume Events?}

Numerous Phanerozoic hotspot and mantle plume events have been proposed, and virtually every Phanerozoic continental and oceanic flood basalt province has been linked to such magmatism. Although not all of these include high-Mg rocks, the time series demonstrates peaks coincident with the eruptions of all proposed pre-Eocene/Phanerozoic hotspots and mantle plumes (fig. 1). For example, there was an important mid-Cretaceous event, termed a "superplume" (Larson 1991). This event significantly increased crustal production during the period 120-80 Ma. Features including the Ontong-Java Plateau, the Naturaliste Plateau, Broken Ridge, the Rio Grande Rise, and the Caribbean Plateau formed during this time (table 3). In fact, there appear to be two pulses in crustal production between 120 and $80 \mathrm{Ma}$ (table 3). Both are captured in our time series analysis (fig. 2), although not all of these features were included in the data set. (To date, high-Mg lavas have only been found associated with obducted portions of the Caribbean Plateau).

Mantle plumes have been invoked to explain gi- ant dike systems like the 2473-Ma Matachewan swarm, Fe-rich quartz tholeiites whose areal extent exceeds 250,000 $\mathrm{km}^{2}$ (LeCheminant and Heaman 1989; Heaman 1997; Ernst and Buchan 2001). Similarly, the $800 \mathrm{Ma}$ Willouran sequence and the coeval Gairdner dike swarm have been attributed to mantle plume volcanism (Forbes 1990; Park et al. 1995; Wingate et al. 1998; Li et al. 1999). These sequences had complex source magmas comprising high-Mg mantle plume melts diluted by the incorporation of sublithospheric or lithospheric material (Condie et al. 1987; Nelson et al. 1990). However, like the oceanic plateaus discussed above, neither of these sequences are known to contain high- $\mathrm{Mg}$ rocks, and, therefore, they are not included in the database examined here. Nevertheless, coeval peaks in the record of high-Mg magmatism are observed (fig. 1). This may reflect simultaneous stimulation of numerous hotspots globally during mantle plume volcanism. It might also demonstrate the range in degree of dilution occurring when magmas generated by a single large mantle plume encounter lithosphere of varying thicknesses.

However, two well-known Precambrian magmatic events are not captured by the data set. The first is the 1267 Mackenzie Dike Swarm, diabase intrusions extending for $2100 \mathrm{~km}$ from the focal point, and the contemporaneous Nauyat Plateau, Coppermine River, and Seal Lake basalts (LeCheminant and Heaman 1989; Romer et al. 1995). The second is the 723-Ma Franklin event, recorded in the Natkusiak flood basalts and Franklin sills and dikes that extend across $2500 \mathrm{~km}$ (Heaman et al. 1992; Rainbird 1993). Both the Mackenzie and Franklin events occurred during rifting of the Superior craton and both have been related to mantle plume volcanism (LeCheminant and Heaman 1989; Heaman et al. 1992).

Perhaps these rocks do not reflect mantle plume activity but some other process. This alternative seems particularly unattractive because the size and circular areal expressions of these events (the geometries of the giant dike swarms and/or domal cratonic uplift) correspond so readily with models of underlying mantle plumes (LeCheminant and Heaman 1989; Heaman et al. 1992; Rainbird 1993). Furthermore, the Muskox intrusion (contemporaneous with Mackenzie events) has a geochemistry consistent with a picritic magma mixed with both a fractionated magma and liquids assimilated from the wall rock (Francis 1994; Roach et al. 1998). So there is evidence for picritic melts in the record of Mackenzie events, although they do not meet the criteria of the data set we investigate here. It is not completely clear whether the data set is biased 
Table 3. Select Mesozoic-Cenozoic Hotspots and Their Magmatic Expressions

\begin{tabular}{|c|c|c|c|}
\hline Hotspot & Attributed sequence & Sequence age & Source \\
\hline \multicolumn{4}{|c|}{ Active at $120 \pm 5 \mathrm{Ma}$ : } \\
\hline Kerguelen? & Bunbury Basalts & $126.5 \pm 3.5$ & Storey et al. 1992 \\
\hline Tristan? & Maranhao Province & $126.5 \pm 2.5$ & Baksi and Archibald 1997 \\
\hline Kerguelen & Naturaliste Plateau & $12 \overline{4}$ & Mahoney et al. 1995 \\
\hline Marion & Masirah Ophiolite & $123 \pm 3$ & Smewing et al. 1991 \\
\hline Louisville? & Ontong-Java Plateau & $123.5 \pm 1.5$ & $\begin{array}{l}\text { Richards et al. 1991; } \\
\text { Mahoney et al. } 1993\end{array}$ \\
\hline Kerguelen & Kerguelen Plateau & $117.5 \pm 1.5$ & Storey 1995 \\
\hline Kerguelen? Crozet? & Rajmahal Basalts & $117 \pm 2$ & $\begin{array}{l}\text { Baksi et al. 1987; Curray and } \\
\text { Munasinghe 1991; Baksi } 1995\end{array}$ \\
\hline \multicolumn{4}{|l|}{ Active at $90 \pm 5 \mathrm{Ma}$ : } \\
\hline Kerguelen & Broken Ridge & $92.5 \pm 2.5$ & Coffin and Eldholm 1994 \\
\hline Louisville? & Ontong-Java Plateau & $92 \pm 2$ & Tejada et al. 1996 \\
\hline Galápagos & $\begin{array}{l}\text { Caribbean Plateau (Gorgona, } \\
\text { Tortugal, Curaçao, Romeral } \\
\text { and Duarte sequences) }\end{array}$ & $90 \pm 5$ & $\begin{array}{l}\text { Richards et al. 1991; Kerr et al. 1996; } \\
\text { Spadea et al. } 1999\end{array}$ \\
\hline Marion & Madagascar Flood Basalts & $88 \pm 3.3$ & Storey et al. 1995 \\
\hline Tristan da Cunha & Rio Grande Rise & $88 \pm 1$ & Larson 1991; Storey 1995 \\
\hline Trindade & Lages Flood Basalt & $87 \pm 2$ & Gibson et al. 1999 \\
\hline \multicolumn{4}{|l|}{ Active at $60 \pm 5 \mathrm{Ma}$ : } \\
\hline Yellowstone & Carmacks Lavas & $69.5 \pm 5$ & Grond et al. 1984; Lowey et al. 1986 \\
\hline Reunion & Pahr Formation & $69.5 \pm 4.5$ & McCormick 1991 \\
\hline Reunion & Deccan Traps & $66.5 \pm 4.3$ & Peng and Mahoney 1995 \\
\hline Iceland & $\begin{array}{l}\text { North Atlantic Tertiary Province } \\
\text { (Greenland, Skye, and Mull) }\end{array}$ & $58 \pm 4$ & Mussett 1986; Storey et al. 1998 \\
\hline
\end{tabular}

against certain mantle plume events /whose magmas were diluted by other melts) or whether Mackenzie and Franklin magmatism cannot be attributed to mantle plumes. In fact, while most accept that the Mackenzie and Franklin events record mantle plume magmatism, a contradictory model has been developed recently for the first.

Yale and Carpenter (1998) suggest Mackenzie magmatism resulted from a catastrophic mixing of the mantle (after the model of Tackley et al. 1993). They relate this extreme modification of mantle convection to the heat-insulating effects of a supercontinent comprising Superior and other blocks. They invoke Rodinia as the supercontinent, while acknowledging that the amalgamation of Rodinia is generally accepted to have occurred at about 1.1 Ga (Dalziel 1997), almost 170 m.yr. later than the Mackenzie events.

Our data set cannot capture an event characterized by dilution of plume material to the extent that $\mathrm{MgO}$ in the resulting rocks is $<10 \mathrm{wt} \%$. The opportunity for dilution of plume-derived lavas increases through time as continents grow. Nonetheless, it is heartening that well-known large events like the Matachewan and the Willouran correspond to peaks in the temporal record of high- $\mathrm{Mg}$ magmatism, although they do not themselves have high-Mg rocks. Further, the data set captures all Phanerozoic hotspot/mantle plume events. While we acknowledge that the two Late Precambrian se- quences described above are missing, we infer that the data set analyzed here is a generally robust indicator of mantle plume activity through time.

\section{Hotspots and Mantle Plumes: Semantics or Significant Differences?}

Oftentimes, the terms "hotspot" and "mantle plume" are used interchangeably. However, most recommend distinguishing between these features on the basis of scale (Abbott 1995). Mantle plumes produce mafic magmatism over regions the order of $10^{3} \mathrm{~km}$ wide. Hotspots are narrower, on the order of $10^{2} \mathrm{~km}$ wide or less. The voluminous magmatism associated with a plume occupies a period shorter than about 10 m.yr., while hotspots like the one underlying Hawaii can erupt lavas for tens of millions of years. Today, while there are 41 active hotspots, only the South Pacific Superswell might be considered a (remnant?) mantle plume (Vinnik et al. 1997), although even this is arguable (Devey et al. 1990; McNutt 1998). The terms "hotspot" and "mantle plume" are therefore not synonymous. It may be better, for example, to invoke "hotspot volcanism" than "small plume" to explain a flood basalt sequence of limited areal extent.

Evidence supports a geographic link between some modern hotspots and ancient flood basalts (Richards et al. 1989). Some, therefore, have suggested a paragenetic link between mantle plumes 
and hotspots (Campbell et al. 1989). However, this is tenuous. For example, there is no clear relationship between the largest Phanerozoic flood basalt, the Siberian Traps, and any hotspot (or hotspot trace). The size of the Siberian Traps and the concurrent eruption of the Emeishan flood basalts suggest a scale of volcanism consistent with a mantle plume.

Other flood basalts do demonstrate a strong geographic link to a hotspot, and, therefore, it seems likely that hotspots alone are capable of generating flood basalts without invoking a larger mantle plume. Such a model is consistent with the Deccan Traps, which fall on a line between the Maastrichtian Parh Formation and the Laccadives-MaldivesChagos-Reunion chain. These have all been attributed to the Reunion hotspot (McCormick 1991; Peng and Mahoney 1995). Similarly, the HawaiianEmperor seamount chain reflects narrow hotspot volcanism, consistent with seismic tomographic imaging (Ying and Nataf 1998). The lavas erupting at Hawaii have a geochemical signature consistent with the introduction of material from the deep mantle and outer core (Brandon et al. 1999; Norman and Garcia 1999). Although it has been disputed, the ca. $125 \mathrm{Ma}$ eruptions on the Ontong-Java Plateau may have been related to the Louisville hotspot (Mahoney et al. 1993).

Therefore, hotspots and plumes leave quite similar regional records; again, the differences may be nothing more than a matter of scale. In some ways, the designations "hotspot" and "mantle plume" are a matter of semantics, rather than representing any significant difference between the two sorts of features. This is particularly true when one considers the Precambrian record. Storey et al. (1990) and Kusky and Kidd (1992) hypothesized that a Precambrian mantle plume event would result in numerous coeval komatiitic sequences accreted to several cratonic blocks. However, it is possible that the simultaneous stimulation of several hotspots could produce oceanic edifices (plateaus and/or ridges and/or seamounts) that would have wide geographic distribution at the time of their creation, enabling them also to be eventually accreted to several cratons. It would be difficult to discern a Precambrian mantle plume event from an event involving several hotspots.

There is, in fact, some evidence that hotspots do demonstrate synchronous pulsation and that the pulsation has a period of about 30 m.yr. (table 3). For example, between about 125 and $115 \mathrm{Ma}$, the Kerguelen and Marion hotspots were particularly active (producing the Naturaliste and Kerguelen Plateaus and the Masirah ophiolite, respectively;
Smewing et al. 1991; Mahoney et al. 1995; Storey 1995). The Tristan, Louisville, and Crozet hotspots may also have been unusually productive during this period, with eruption of the bulk of the Ontong-Java Plateau and several continental flood basalt provinces (table 3; Richards et al. 1991). About 30 m.yr. later (ca. $90 \mathrm{Ma}$ ), several hotspots produced important volcanic sequences, including the Caribbean Plateau, Broken Ridge, the Rio Grande Rise, and Lages and Madagascar flood basalts (table 3). There was renewed volcanic activity on the Ontong-Java Plateau (Tejada et al. 1996). Approximately $30 \mathrm{~m} . y r$. later, the Yellowstone, Reunion, and Iceland hotspots were all unusually active (table 3). Crustal production at the Afar hotspot increased about $30 \mathrm{~m}$.yr. later at ca. $30 \mathrm{Ma}$, with eruption of flood sequences in Ethiopia and Yemen (Baker et al. 1996; Hofmann et al. 1997).

Increased volcanic activity at several global hotspots may explain why crustal production at ridge crests and rates of plate motion have increased during some "mantle plume" events (Larson 1991; Sheridan 1997). Therefore, when we use the term "mantle plume" below, we mean an event corresponding to increased eruption of high- $\mathrm{Mg}$ lavas. Such magmatism could have been promoted by a single mantle plume impacting Earth's surface or by numerous (perhaps widely dispersed) hotspots.

\section{Temporal Trends in the Data Set}

The interior of the Earth has been cooling through geologic time as radioisotopes decay (Lambert 1976). Heat from the interior of the Earth is dissipated in several ways: by crustal production along mid-ocean ridges, hotspots, and mantle plumes; by hydrothermal circulation; and by conductive cooling through the lithosphere (Sclater et al. 1980). If the relative importance of each of these factors remains constant through time, then the magnitude of mantle plume volcanism (and numbers of highMg events) should decrease as Earth's interior heat flow decreases. Because erosion also affects the record, there should be increasing retention of high$\mathrm{Mg}$ events through time. The cumulative effect of reduced mantle plume volcanism and increased retention should result in one of three sorts of curves. If the first process outweighs the importance of the second, figure 1 should show a monotonic (and likely exponential) decrease in the number of high$\mathrm{Mg}$ events through time. If the second process outweighs the importance of the first, figure 1 should show an exponential growth in the number of high$\mathrm{Mg}$ events through time (e.g., by analogy with curves expressing the temporal distribution of car- 
bonatites; Veizer et al. 1992). If both processes are of roughly equal importance, then figure 1 should document a U-shaped curve.

None of these trends are observed unambiguously in figure 1. Instead, there is a significant peak at ca. 2.7 Ga. This is about $0.2-0.7 \mathrm{Ga}$ younger than the major phase of continental growth postulated by Taylor and McLennan (1985), although it corresponds very well with Condie's model of episodic crustal formation (Condie 1995, 2000). Not only high-Mg lavas but a number of other geologic indicators are focused at $2.7 \mathrm{Ga}$, suggesting a major magmatic event. These include peaks in the numbers of continental and oceanic flood basalts, greenstone belts, and examples of $\mathrm{Ni}, \mathrm{Cu}$, and $\mathrm{Zn}$ mineralization (Kusky and Kidd 1992; Nelson et al. 1992; Blake 1993; Desrochers et al. 1993; Condie 1995; Barley et al. 1998). Peaks are also observed in numbers of black carbonaceous shales and banded iron formation (Barley et al. 1998; Isley and Abbott 1999). Assuming that subduction and erosion have eradicated a significant portion of the 2.7Ga record, then surely all indicators suggest that this was one of the most important mantle plume events in Earth history.

This inference requires that mantle plume volcanism has not decreased monotonically through time as has Earth's radiogenic heat flow. There are also models that relate mantle plume magmatism to the transfer of subducted lithosphere to the deep mantle with an attendant perturbation of the $\mathrm{D}^{\prime \prime}$ layer. However, De Wit (1998) recently proposed that modern-style subduction did not begin (or did not work efficiently) until the Late Archean. If his hypothesis is correct, then such a model is not viable to explain the 2.7-Ga event nor can the insulating effects of a supercontinent be what promulgates this peak; the notion of a supercontinent Vaalbara, consisting of (at minimum) the Kaapvaal and Pilbara cratons, is not supported by lithostratigraphic or paleomagnetic data (Wingate 1998; Nelson et al. 1999).

If we ignore the peak near $2.7 \mathrm{Ga}$, the Archean and Paleoproterozoic record is punctuated by peaks in high-Mg volcanism that are of roughly equivalent height and occur about every 200-300 m.yr. (fig. 1). This may reflect the fact that plume events in this period predominantly impacted oceanic lithosphere. Thus, the oceanic edifices that they built were retained. Mantle plumes arriving under oceanic lithosphere produce ocean plateaus, seamounts, and aseismic ridges (Larson 1991). These sorts of oceanic edifices have much thicker crust than is formed at mid-ocean ridges (Klein and Langmuir 1987; McKenzie and Bickle 1988). Because they are unusually thick and buoyant, the features derived from mantle plume volcanism are likely to be accreted, at least in part, rather than subducted (Ben-Avraham et al. 1981; Cloos 1993; Abbott and Mooney 1995). In fact, several Archean and Paleoproterozoic sequences have been interpreted as accreted ocean plateaus (Boher et al. 1992; Kusky and Kidd 1992; Desrochers et al. 1993; Puchtel et al. 1998b, 1999; Hollings and Kerrich 1999). Therefore, the fact that there was much less continental crust in the Archean may have very little to do with the retention of high-Mg lavas in the record. This suggests a regular periodicity to mantle plume volcanism through time, reflected in the energetic 273 m.yr. spectral period.

Two plume events in the MesoproterozoicNeoproterozoic portion of the record are suggested by the record of high-Mg magmatism. These are centered near 1.1 and $0.8 \mathrm{Ga}$ (fig. 1). If the Mackenzie and Franklin events are included, then four plume events occurred between 1650 and $500 \mathrm{Ma}$ : centered about 1.3 (Mackenzie), 1.1 (Midcontinent Rift), and 0.7 Ga (Franklin). Given the 266-m.yr. period permeating the time series, one would infer at least four plume events between 1650 and 550 Ma. When the Mackenzie and Franklin events are included, the 300-m.yr. spacing between events at 1.1 and $0.8 \mathrm{Ga}$ is analogous to the spacing between other peaks in the Archean-Proterozoic and Phanerozoic portions of the record (fig. 1).

The 300-m.yr. period lacking evidence for high$\mathrm{Mg}$ volcanism (1.1-0.8 Ga) coincides approximately with a putative supercontinent, Rodinia (Unrug 1997; Weil et al. 1998). Models suggesting that supercontinents promote plume-style volcanism by insulation of the mantle are not supported by the lack of high-Mg activity and widespread flood basalt volcanism during the 300-m.yr. life of Rodinia, unless the mantle must be insulated for hundreds of millions of years before eruptions eventually occur (see Yale and Carpenter 1998). Another model relates flood basalt volcanism to variations in lithospheric thickness, so that subhorizontal flow brings hot material to the boundary juxtaposing older, thicker crust and younger, thinner crust (King and Anderson 1995). Again, this model is abrogated by the 300-m.yr. lifetime of Rodinia, given typical mantle flow rates.

\section{Driving Forces of Mantle Plume Volcanism}

We do not find evidence for models promoting a tectonic origin for high-Mg magmatism. Most of the high-Mg units in the data set are associated with greenstone belt volcanics or flood basalt se- 
quences. Models suggesting high temperature (or voluminous) magmatism related somehow to the formation of supercontinents are not supported by the time series peak at $2.7 \mathrm{Ga}$ or by the geologic record at the time of the supercontinent Rodinia. These models imply a tectonic driving force and therefore a tectonic (Wilson Cycle) periodicity to mantle plume events: one longer than the 273m.yr. period and one shorter than the 800-m.yr. period (table 2). What then is driving mantle plume volcanism on Earth?

Longest Period Energy. The largest fraction of the energy in the 4096-0 m.yr. data set is concentrated in the $819+204 /-137-m$.yr. period (table 2). This period is reflected in the regular temporal spacing of peaks at ca. 2.7, 1.9, 1.1, and $0.4 \mathrm{Ga}$ (fig. 1). The 800-m.yr. period is significantly longer than the length of periodic, tectonically driven processes.

Some modelers have suggested the mantle overturns every ca. $1 \mathrm{Ga}$, promoting important magmatic events (Tackley et al. 1993; Davies 1995, 1997). Mantle plumes might be generated when the temperature structure near the $\mathrm{D}^{\prime \prime}$ layer is perturbed by subducted lithospheric slabs cascading beyond the 670-km-deep seismic discontinuity (Condie 1995; Sheridan 1997). In particular, Condie (Condie $1995,1997,2000$ ) has suggested such events at 2.7, 1.9 , and 1.2 Ga. The first two "superevents" correlate with the largest Precambrian mantle plumes suggested by the high-Mg record.

Others have suggested that particularly large events may be driven by resonant core nutations. Briefly, modeling results suggest that Earth's forced nutations (the periodic tipping of the Earth's spin axis as a result of solar and lunar gravitational pulls) can resonate with the Earth's free-core nutation (Williams 1994; Greff-Lefftz and Legros 1999). The half-annual resonance occurred during the Precambrian, and the annual resonance occurred during the Phanerozoic. During these events, the heat flux from the core-mantle boundary may have doubled and material movement in the core may have increased by orders of magnitude (Hinderer et al. 1987; Williams 1994). It is therefore interesting that eruptions of high- $\mathrm{Mg}$ lavas are concentrated in the 3.2-2.4-Ga time slice and in the past 800 m.yr. (fig. 1 ; table 1).

Workers have tended to match the one-third or one-half annual resonance to the 2.7-Ga event (Williams 1994; Greff-Lefftz and Legros 1999), which is documented here by a peak in the number of high$\mathrm{Mg}$ events and which includes komatiite "rivers" and thick ferropicritic flows. Workers also have inferred that resonance between the free-core nutation and the annual forced nutation promoted increased crustal production. Williams (1994) attributed magmatism associated with the Iapetan Rift to this event. Others have suggested that the Siberian Trap basalts may mark it (Greff-Lefftz and Legros 1999).

Length-of-day arguments yield a 22.2-22.7-h day at the annual resonance that is difficult to reconcile with the 90-60-Ma peak in high-Mg magmatism and that appears much too short to be associated with the Siberian Traps. If one assumes a 22-h day at the start of the Phanerozoic (cf. Williams 2000 ), the $22.45 \pm 0.25$-h day is clearly Paleozoic $(418.5 \pm 67.5 \mathrm{Ma})$. The period after about $400 \mathrm{Ma}$ is marked by renewed high- $\mathrm{Mg}$ volcanism, culminating in a peak at 380-360 Ma (fig. 1). For the first time in about $800 \mathrm{~m} . y r .$, komatiites erupt; the earliest meimechites are also of this age. Alkaline volcanism increases globally, with emplacement of lamproite and carbonatite dikes and kimberlites in China and the Kola Peninsula (Veizer et al. 1992; Haggerty 1994; Lu et al. 1995; Beard et al. 1996). Carbonatites are rich in Fe (ankeritic carbonatite or ferrocarbonatites), and kimberlites are rich in $\mathrm{Ti}$, $\mathrm{Fe}, \mathrm{Mg}, \mathrm{Ni}$, and $\mathrm{Cr}$ (Beard et al. 2000; Claesson et al. 2000). Light noble gases in carbonatites confirm a deep-seated mantle source, delivered by a mantle plume (Marty et al. 1998).

Assuming that 2.7- and 0.4-Ga events marked resonance between the free-core nutation and onethird annual and annual forced nutations, then the one-half annual resonance occurred about $1.9 \pm$ $0.2 \mathrm{Ga}$. This time is one of enhanced eruption of high-Mg lavas, and other manifestations of plumedriven magmatism, including flood basalts on West Africa, Baltica and the Superior craton, mafic dike swarms on the Dharwar, Lewisian, Nain, and Kaapvaal cratons, and large layered igneous intrusions, including the Bushveld (Parrish 1989; Abouchami et al. 1990; Puchtel et al. 1997, 1998a; Cornell et al. 1998; Isley and Abbott 1999). We find the hypothesis that resonance between free-core and forced-core nutations influenced mantle plume activity intriguing and suggest it should be explored further (Isley and Abbott 2001).

Strongest Periods in Data Subsets. The strongest periods in both 256-m.yr.-long data subsets are $26 \pm 3$ and $34.5 \pm 4.5 \mathrm{~m}$.yr. These latter, roughly equivalent periods are analogous to those observed in numerous other time series investigated by Rampino and Stothers (1984) and Rampino and Caldeira (1993). Impacts are modulated by galactic tidal perturbation of the Oort cloud by the Sun's oscillation perpendicular to the galactic plane with a 30-35m.yr. period (Rampino and Stothers 1984; Matese et al. 1996; Shoemaker 1998). Thus, others have 
proposed a link between impacts and flood basalt volcanism (Rogers 1982; Rampino and Stothers 1984).

As Fischer and Arthur first observed (1977), a remarkable set of geologic time series demonstrates periods near $32 \mathrm{~m}$.yr. Climatic cycles over the past 100 m.yr. have a periodicity of 33-38 m.yr. (Kaiho and Saito 1994). Sea-level variations over the past 200 m.yr. demonstrate a 33-m.yr. periodicity (Negi et al. 1990). Sea-floor spreading jumps, continental rifting, volcanism, and enhanced orogeny (all of which may affect climate change) demonstrate periods of 26-34 m.yr. (Rampino and Caldeira 1993). Atmospheric $\mathrm{CO}_{2}$ has risen and fallen with a 32m.yr. beat (Tiwari and Rao 1998).

Could cometary impacts influence the generation of all high-Mg lavas? Stothers (1989) warned that Phanerozoic stage boundaries display a weak period of $28 \mathrm{~m}$.yr. and that use of time series ages constrained by biostratigraphy could yield erroneous results when subjected to spectral analysis. However, the $26 \pm 3$-m.yr. period that dominates the Archean data subset cannot be such an artifact.

Glikson $(1996,1999)$ suggested that impacts were connected to magmatism and/or rifting at the Cretaceous-Tertiary boundary, in the Jurassic, and at the Permo-Triassic boundary. A ca. 400-m.yr.old crater is known from the Ukraine (Gurov et al. 1998), and large diameter craters whose ages are consistent with the mantle plume event at about $370 \mathrm{Ma}$ include Charlevoix $(54 \mathrm{~km})$, Kaluga (15 $\mathrm{km})$, and Siljan $(53 \mathrm{~km})$. These plume events are all captured in the high-Mg data set (fig. 1), and we find the correlation between the Phanerozoic record of mantle plume magmatism and impacts striking.

Spherules recording Precambrian impacts form layers in the Australian Hamersley Group that are $2.63,2.56,2.54$, and $2.45 \mathrm{Ga}$ old (Simonson et al. 1998; Simonson 2000). The Vredefort event was 2.01 Ga (Gibson et al. 1997), and the Sudbury impact was $1.85 \mathrm{Ga}$ (Ostermann et al. 1996). Some of these correspond to periods of enhanced magmatism, with a particularly important event at 2.45 Ga (Heaman 1997). Others do not show such correspondence (cf. fig. 1), and in particular, no 2.7-Ga impact event is known. Nonetheless, given the manner in which erosion and subduction has obscured the record of impacts, it is quite interesting that there is some temporal correspondence between Precambrian impacts or spherule layers and mantle plume activity.

In the context of the impact-driven mantle plume model, it is particularly noteworthy that extreme disturbances of the Oort cloud occur approximately every $750 \mathrm{~m}$.yr. by grazing encounters with nebulae (Napier 1998). The cosmic year also modulates impacts by disturbing the Oort cloud. The length of the cosmic year currently is estimated to be 274-285 m.yr., ranging to 400 m.yr. in the Early Archean (Steiner and Grillmair 1973; Chen 1984). These periodicites are quite analogous to the 800m.yr. and 273-m.yr. energies that we find permeating the entire 4-b.yr.-long time series.

However, there are alternative models to explain the longer-period energies, as discussed above. There are also alternative models to explain shorter-period pulses in magmatism. For example, Olson et al. (1987) suggested that plumes travel in dispersive conduit waves, with propagation speeds that vary over an order of magnitude. Arrival of different wave packets at the surface may contribute to episodic plume volcanism. According to van Keken and Gable (1995), plumes pulsate because of the interaction between plumes and the rheological interface at the transition zone. The frequency of pulsation would then relate to the Rayleigh number and the viscosity contrast. Larsen et al. (1996) developed a model of mantle convection consisting of initial high rates of crustal formation lasting a few millions of years, followed by pulsating magmatic activity. Although these models are intriguing, they do not result in a periodicity analogous to $30 \mathrm{~m}$.yr. but promote bursts in magmatism every 4-10 m.yr. We therefore favor the hypothesized relationship between impacts and mantle plume volcanism, and we explore the meaning of the ca. 30m.yr. periodicity more fully in a future article (Abbott and Isley, in press).

\section{Changes in High-Mg Lithologies through Time}

There is a clear trend to more Ti-rich lavas through time. Komatiites and, in fact, all rocks with a komatiitic constituent are rare after 1.6 Ga. Picrites (as defined by the 1989 IUGS classification) increase after $1.6 \mathrm{Ga}$, peaking in the $0.8-0 \mathrm{Ga}$ time slice. During the past 800 m.yr., alkaline lavas (ankaramites and meimechites) have appeared. Picrites, ankaramites, and meimechites may all be perceived as modern, Ti-rich analogs of komatiites. All of these lithologies are found most frequently in rocks erupted or emplaced in intracratonic settings by hotspots and mantle plumes.

Campbell and Griffiths (1990) first suggested that heterogeneity in plume-generated magmas might reflect transfer of Early-Middle Archean plates to depth, and their assimilation in the mantle. The long-term trend to high- $\mathrm{Mg}$ rocks that are richer in $\mathrm{Ti}$ could be explained by reintroduction of Ti from 
eroded and subducted continental material or oceanic crust to the mantle. Rudnick et al. (2000) propose that Ti was sequestered in refractory eclogite but find that mass balances also require a Ti reservoir in the lower mantle, perhaps close to the core-mantle boundary. This model is supported by our results that indicate that plume magmas have become more Ti-rich through time.

\section{Conclusions}

Mantle plume events have occurred about every 300 m.yr. through time. There was a particularly large event at $2.7 \mathrm{Ga}$. High-Mg rocks erupted during plume events through Earth history are increasingly rich in $\mathrm{Ti}$, and picrites, ankaramites, and meimechites are the modern analogs for komatiites. Several processes have been discussed that may drive a ca. 800-m.yr. periodicity in mantle plume volcanism, including impacts, cascade of tectonic slabs into the mesosphere, and resonance between free-core nutations and those forced by solar torques. Superimposed on the long cycle is a 273m.yr. period that we think represents the cosmic year and energies of about $30 \mathrm{~m}$.yr. The importance of the latter in both Archean and Phanerozoic data subsets bolsters the proposed link between cometary impacts and mantle plume volcanism. Mafic magmatism and crustal production rates during an event exemplified by simultaneous stimulation of widely separated hotspots can be as significant as during a mantle plume event sensu strictu.

\section{A C K N O W L E D G M E N T S}

We thank J. Chiarenzelli and D. Thomas for reviewing an earlier draft of this article. We appreciate helpful reviews from R. Ernst and an anonymous reviewer, and we thank them for their comments. A. E. Isley thanks the librarians at Penfield Library, State University of New York College at Oswego, for completing the paperwork involved in obtaining articles used in this study.

\section{R E F E R E N C E S C I T E D}

Abbott, D. 1995. Plumes and hotspots as sources of greenstone belts. Lithos 37:113-127.

Abbott, D.; Burgess, L.; Longhi, J.; and Smith, W. H. F. 1994. An empirical thermal history of the Earth's upper mantle. J. Geophys. Res. 99:13,835-13,850.

Abbott, D., and Mooney, W. 1995. The structural and geochemical evolution of the continental crust: support for the oceanic plateau model of continental growth. U.S. National Report to International Union of Geodesy and Geophysics. Rev. Geophys. Suppl. 1991-1994:231-242.

Abbott, D. H., and Isley, A. E. In press. The case for strengthening of mantle plumes by large impacts. Earth Planet. Sci. Lett.

Abouchami, W.; Boher, M.; Michard, A.; and Albarede, F. 1990. A major 2.1 Ga event of mafic magmatism in West Africa: an early stage of crustal accretion. J. Geophys. Res. 95:17,605-17,629.

Alvarado, G. E.; Denyer, P.; and Sinton, C. W. 1997. The $89 \mathrm{Ma}$ Tortugal komatiitic suite, Costa Rica: implications for a common geological origin of the Caribbean and Eastern Pacific from a mantle plume. Geology 25:439-442.

Amelin, Y. V.; Heaman, L. M.; and Semenov, V. S. 1995. $\mathrm{U}-\mathrm{Pb}$ geochronology of layered mafic intrusions in the eastern Baltic Shield: implications for the timing and duration of Paleoproterozoic continental rifting. Precambrian Res. 75:31-46.

Arndt, N.; Cheadle, M.; Herzberg, C.; Jenner, G.; Lahaye,
Y.; Ginibre, C.; Chauvel, C.; and Albarede, F. 1998. Were komatiites wet? Geology 26:739-742.

Baker, J.; Snee, L.; and Menzies, M. 1996. A brief Oligocene period of flood volcanism in Yemen: implications for the duration and rate of continental flood volcanism at the Afro-Arabian triple junction. Earth Planet. Sci. Lett. 138:39-55.

Baksi, A. K. 1995. Petrogenesis and timing of volcanism in the Rajmahal flood basalt province, northeastern India. Chem. Geol. 121:73-90.

Baksi, A. K., and Archibald, D. A. 1997. Mesozoic igneous activity in the Maranhao Province, northern Brazil: ${ }^{40} \mathrm{Ar} /{ }^{39} \mathrm{Ar}$ evidence for separate episodes of basaltic magmatism. Earth Planet. Sci. Lett. 151:139-153.

Baksi, A. K.; Barman, T. R.; Paul, D. K.; and Farrar, E. 1987. Widespread Early Cretaceous flood basalt volcanism in eastern India: geochemical data from the RajmahalBengal-Sylhet traps. Chem. Geol. 63:133-141.

Barley, M. E.; Kerrich, R.; Krapez, B.; and Groves, D. I. 1998. The late Archaean bonanza: metallogenic and environmental consequences of the interaction between mantle plumes, lithospheric tectonics and global cyclicity. Precambrian Res. 91:65-90.

Basu, A. P. 1995. High- ${ }^{3} \mathrm{He}$ plume origin and temporalspatial evolution of the Siberian flood basalts. Science 269:822-825.

Beard, A. D.; Kempton, P. D.; Maluski, H.; Downes, H.; and Vetrin, V. 1996. Petrogenesis of Devonian lamprophyre and carbonatite minor intrusions, Kandalaksha Gulf (Kola Peninsula, Russia). Lithos 39:93-119. 
Beard, A. D.; Sablukov, S. M.; Downes, H.; and Hegner, E. 2000. Geochemistry and mineralogy of kimberlites from the Arkhangelsk region, NW Russia: evidence for transitional kimberlite magma types. Lithos 51: 47-73.

Ben-Avraham, Z.; Nur, A.; Jones, D.; and Cox, A. 1981. Continental accretion: from oceanic plateaus to allochthonous terranes. Science 213:47-54.

Bhattacharji, S.; Chatterjee, N.; Wampler, J. M.; Nayak, P. N.; and Deshmukh, S. S. 1996. Indian intraplate and continental margin rifting, lithospheric extension, and mantle upwelling in Deccan flood basalt volcanism near the $\mathrm{K} / \mathrm{T}$ boundary: evidence from mafic dike swarms. J. Geol. 104:379-398.

Blake, T. S. 1993. Late Archean crustal extension, sedimentary basin formation, flood basalt volcanism and continental rifting: the Nullagine and Mount Jope Supersequences, Western Australia. Precambrian Res. 60:185-241.

Boher, M.; Abouchami, W.; Michard, A.; Abelarde, F.; and Arndt, N. T. 1992. Crustal growth in West Africa at 2.1 Ga. J. Geophys. Res. 97:345-369.

Brandon, A. D.; Morgan, J. W.; Norman, M. D.; and Walker, R. J. 1999. ${ }^{186} \mathrm{Os}^{-{ }^{187}}$ Os systematics of Hawaiian picrites. Earth Planet. Sci. Lett. 174:25-42.

Buick, R.; Thornett, J. R.; McNaughton, N. J.; Smith, J. B.; Barley, M. E.; and Savage, M. 1995. Record of emergent continental crust $\sim 3.5$ billion years ago in the Pilbara craton of Australia. Nature 375:574-577.

Burke, K. 1997. Foreward. In De Wit, M. J., and Ashwal, L. D., eds. Greenstone belts. Oxford, Clarendon Press, p. v-vii.

Buturlinov, N. V., and Kisil', S. I. 1985. Development of Devonian volcanism in the articulation zone of the Donets Basin and Azov Sea crystalline massif. Dopov. Akad. Nauk Ukr. RSR Ser. B Heol. Khim. Biol. Nauky $1: 3-6$.

Campbell, I. H., and Griffiths, R. W. 1990. Implications of mantle plume structure for the evolution of flood basalts. Earth Planet. Sci. Lett. 99:79-93.

Campbell, I. H.; Griffiths, R. W.; and Hill, R. I. 1989. Melting in an Archaean mantle plume: heads it's basalts, tails it's komatiites. Nature 339:697-699.

Chen, X. 1984. On the evolution of the Earth in relation to the galactic system-a rough discussion of cosmogeological views. Geochimica 3:256-268.

Claesson, S.; Downes, H.; Vetrin, V.; and Bayanova, T. 2000. U-Pb zircon ages from a Devonian carbonatite dyke, Kola Peninsula, Russia: a record of geological evolution from the Archaean to the Paleozoic. Lithos 51:95-108.

Cloos, M. 1993. Lithospheric buoyancy and collisional orogenesis: subduction of oceanic plateaus, continental margins, island arcs, spreading ridges, and seamounts. Geol. Soc. Am. Bull. 105:715-737.

Coffin, M. F., and Eldholm, O. 1994. Large igneous provinces: crustal structure, dimensions, and external consequences. Rev. Geophys. 32:1-36.

Condie, K. C. 1995. Episodic ages of greenstones: a key to mantle dynamics? Geophys. Res. Lett. 22: 2215-2218.

- 1997. Contrasting sources for upper and lower continental crust: the greenstone connection. J. Geol. 105:729-736.

- 2000. Episodic continental growth models: afterthoughts and extensions. Tectonophysics 322: 153-162.

Condie, K. C.; Bobrow, D. J.; and Card, K. D. 1987. Geochemistry of Precambrian mafic dykes from the southern Superior Province of the Canadian Shield. Geol. Assoc. Can. Spec. Pap. 34:95-108.

Cornell, D. H.; Armstrong, R. A.; and Walraven, F. 1998. Geochronology of the Proterozoic Hartley Basalt Formation, South Africa: constraints on the Kheis tectonogenesis and the Kaapvaal craton's earliest Wilson Cycle. J. Afr. Earth Sci. 26:5-27.

Curray, J. R., and Munasinghe, T. 1991. Origin of the Rajmahal Traps and the $85^{\circ} \mathrm{E}$ Ridge: preliminary reconstructions of the trace of the Crozet hotspot. Geology 19:1237-1240.

Dalziel, I. W. D. 1997. Neoproterozoic-Paleozoic geography and tectonics: review, hypothesis, environmental speculation. Geol. Soc. Am. Bull. 109:16-42.

Davies, G. F. 1995. Punctuated tectonic evolution of the Earth. Earth Planet. Sci. Lett. 136:363-379.

1997. The mantle dynamical repertoire: plates, plumes, overturns and tectonic evolution. AGSO J. Aust. Geol. Geophys. 17:93-99.

Desrochers, J. P.; Hubert, C.; Ludden, J. N.; and Pilote, P. 1993. Accretion of Archean oceanic plateau fragments in the Abitibi greenstone belt. Geology 21: 451-454.

Devey, C. W.; Muhe, R.; Stoffers, P.; Albarede, F.; Cheminee, J.-L.; and Michard, A. 1990. Active submarine volcanism on the Society hotspot swell (west Pacific): a geochemical study. J. Geophys. Res. 95:5049-5066.

De Wit, M. J. 1998. On Archean granites, greenstones, cratons and tectonics: does the evidence demand a verdict? Precambrian Res. 91:181-226.

Ernst, R. E., and Buchan, K. L. 1997. Giant radiating dyke swarms; their use in identifying pre-Mesozoic large igneous provinces and mantle plumes. In Mahoney, J. J., and Coffin, M. F., eds. Large igneous provinces; continental, oceanic, and planetary flood volcanism. Geophys. Monogr. 100:297-333.

- 2001. Large mafic magmatic events through time and links to mantle plume heads. In Ernst, R. E., and Buchan, K. L., eds. Mantle plumes: their identification through time. Geol. Soc. Am. Spec. Pap. 352, in press.

Fang, N., and Ma, H. 1994. A Devonian-Carboniferous komatiite, in the southwestern Yunnan, China: a new discovery and its tectonic implications. Geol. Soc. Am. Abstr. Program 26:136.

Fedorenko, V., and Czamanske, G. 1997. Results of new field and geochemical studies of the volcanic and intrusive rocks of the Maymecha-Kotuy area, Siberian flood basalt province, Russia. Int. Geol. Rev. 39: 479-531.

Fedorneko, V. A.; Hawkesworth, C. J.; Wooden, J. L.; Ebel, 
D. S.; Lightfoot, P. C.; Naldrett, A. J.; and Czamanske, G. K. 1996. Petrogenesis of the flood-basalt sequence at Noril'sk, north central Siberia. Int. Geol. Rev. 38: 99-135.

Fischer, A. G., and Arthur, M. A. 1977. Secular variations in the pelagic realm. SEPM (Soc. Sediment. Geol.) Spec. Publ. 25:19-50.

Foden, J. D. 1983. The petrology of the calcalkaline lavas of Rindjani Volcano, East Sundra Arc: a model for island arc petrogenesis. J. Petrol. 2:98-130.

Fodor, R. V., and Hanan, B. B. 2000. Geochemical evidence for the Trindade hot spot trace: Columbia seamount ankaramite. Lithos 51:293-304.

Forbes, B. G. 1990. Geology of the Willouran Ranges. In Jago, J. B., ed. The evolution of a Late Precambrian-Early Paleozoic rift complex: the Adelaide Geosyncline. J. Geol. Soc. Aust. Spec. Publ. 16:68-84.

Francis, D. M. 1994. Chemical interaction between picritic magmas and upper crust along the margins of the Muskox Intrusion, Northwest Territories. Geol. Surv. Can. Spec. Pap. 92-12, 98 p.

Francis, D. M., and Hynes, A. J. 1979. Komatiite-derived tholeiites in the Proterozoic of New Quebec. Earth Planet. Sci. Lett. 44:473-481.

Fukuyama, H. 1983. Geology of Minami-Iwo Volcano, Izu-Bonin Islands, Japan. Chigaku Zasshi (J. Geogr.) 1: 55-59 (in Japanese).

Gibson, R. L.; Armstrong, R. A.; and Reimold, W. U. 1997. The age and thermal evolution of the Vredefort impact structure: a single-grain U-Pb zircon study. Geochim. Cosmochim. Acta 61:1531-1540.

Gibson, S. A.; Mitchell, J. G.; Thompson, R. N.; Leonardos, O. H.; and Dickin, A. P. 1999. The limited extent of plume-lithosphere interactions during continental flood-basalt genesis: geochemical evidence from Cretaceous magmatism in southern Brazil. Contrib. Mineral. Petrol. 137:147-169.

Gibson, S. A.; Thompson, R. N.; and Dickin, A. P. 2000. Ferropicrites: geochemical evidence for Fe-rich streaks in upwelling mantle plumes. Earth Planet. Sci. Lett. 174:355-374.

Glikson, A. Y. 1996. Mega-impacts and mantle-melting episodes: tests of possible correlations. AGSO Aust. J. Geol. Geophys. 16:587-607.

1999. Oceanic mega-impacts and crustal evolution. Geology 27:387-390.

Goncharenko, A. I.; Kortusov, M. P.; and Tat'yanin, G. M. 1981. Alkalic ultramafic volcanic association of the southeastern part of the west Siberian block. Dokl. Akad. Nauk SSSR Earth Sci. Sect. 259:113-117.

Greff-Lefftz, M., and Legros, H. 1999. Core rotational dynamics and geological events. Science 286:1707-1709.

Gromshei, M. M.; Arkani-Hamed, J.; Strangeway, D. W.; and Russell, R. D. 1990. Underplating of oceanic lithosphere in the Archean: a possible mechanism for the formation of Archean komatiites. Tectonophysics 172:291-302.

Grond, H. C.; Nixon, G. T.; Churchill, S. J.; Armstrong, R. L.; and Harakal, J. E. 1984. Late Cretaceous age of the Hutsi, Mount Nansen and Carmacks Groups, southwestern Yukon Territory and northwestern British Columbia (Canada). Can. J. Earth Sci. 21:554-558.

Guest, J. E.; Queiroz, G.; Duncan, M. A.; Wallenstein, N.; Ferreira, T.; Pacheco, J.-M.; Gaspar, J. L.; and Cole, P. D. 1999. Volcanic geology of Furnas volcano, Sao Miguel, Azores. J. Volcanol. Geotherm. Res. 92:1-29.

Gurov, E. P.; Koebert, C.; and Reimold, W. U. 1998. Petrography and geochemistry of target rocks and impactites from the Ilyinets Crater, Ukraine. Meteorit. Planet. Sci. 33:1317-1333.

Haggerty, S. E. 1994. Superkimberlites: a geodynamic diamond window to the Earth's core. Earth Planet. Sci. Lett. 122:57-69.

Hamilton, P. J.; Hickman, A. H.; Evensen, N. M.; O'Nions, R. K.; and Glikson, A. Y. 1981. Sm-Nd dating of the North Star Basalt, Warrawoona Group, Pilbara block, Western Australia. Geol. Soc. Aust. Spec. Publ. 7:187-192.

Hanski, E. J. 1992. Petrology of the Pechenga ferropicrites and cogenetic, Ni-bearing gabbro-wehrlite intrusions, Kola Peninsula, Russia. Bull. Geol. Surv. Finl. 367: $1-196$.

Hawkesworth, C. J.; O'Nions, R. K.; and Arculus, R. J. 1979. $\mathrm{Nd}$ and $\mathrm{Sr}$ isotope geochemistry of island arc volcanics, Grenada, Lesser Antilles. Earth Planet. Sci. Lett. 45:237-248.

Heaman, L. M. 1997. Global mafic magmatism at 2.45 $\mathrm{Ga}$ : remnants of an ancient large igneous province? Geology 25:299-302.

Heaman, L. M.; LeCheminant, A. N.; and Rainbird, R. H. 1992. Nature and timing of Franklin igneous events, Canada: implications for a Late Proterozoic mantle plume and the break-up of Laurentia. Earth Planet. Sci. Lett. 109:117-131.

Heaman, L. M., and Tarney, J. 1989. U-Pb baddeleyite ages for the Scourie dyke swarm, Scotland: evidence for two distinct intrusion events. Nature 340:705-708.

Heisler, J., and Tremaine, S. 1989. How dating uncertainties affect the detection of periodicity in extinctions and craters. Icarus 77:213-219.

Hinderer, J.; Legros, H.; and Amalvict, M. 1987. Tidal motions within the Earth's fluid core: resonance process and possible variations. Phys. Earth Planet. In. 49:213-221.

Hofmann, C.; Courtillot, V.; Féraud, G.; Rouchette, P.; Yirgu, G.; Ketefo, E.; and Pik, R. 1997. Timing of the Ethiopian flood basalt event and implications for plume birth and global change. Nature 389:838-841.

Hollings, P., and Kerrich, R. 1999. Trace element systematics of ultramafic and mafic volcanic rocks from the 3 Ga North Caribou greenstone belt, northwestern Superior Province. Precambrian Res. 93:257-279.

Isley, A. E., and Abbott, D. H. 1999. Plume-related mafic volcanism and the deposition of banded iron formation. J. Geophys. Res. 104:15,461-15,478.

. 2000. Mantle superplumes and eruption of highMg lavas, including komatiites. QUEST, Oswego State University, April 8, 2000 (abstr.).

2001. Testing links between resonant core nu- 
tations and mantle plume volcanism. Am. Geophys. Union Spring Meeting (abstr.).

Jellinek, A. M., and Kerr, R. C. 1999. Mixing and compositional stratification produced by natural convection. II. Applications to the differentiation of basaltic and silicic magma chambers and komatiite lava flows. J. Geophys. Res. 104:7203-7218.

Johnson, K. T. M.; Sinton, J. M.; and Price, R. C. 1986. Petrology of seamounts northwest of Samoa and their relation to Samoan volcanism. Bull. Volcanol. 40: 225-235.

Kaiho, K., and Saito, S. 1994. Oceanic crust production and climate during the last 100 Myr. Terra Nova 6: 376-384.

Kennedy, A. K.; Kwon, S. T.; Frey, F. A.; and West, H. B. 1991. The isotopic composition of postshield lavas from Mauna Kea volcano, Hawaii. Earth Planet. Sci. Lett. 103:339-353.

Kerr, A. C.; Marriner, G. F.; Arndt, N. T.; Tarney, J.; Nivia, A.; Saunders, A. D.; and Duncan, R. A. 1996. The petrogenesis of Gorgona komatiites, picrites and basalts: new field, petrographic and geochemical constraints. In Ludden, J. N.; Arndt, N. T.; and Francis, D., eds. Mafic magmatism through time. Amsterdam, Elsevier, p. $245-260$.

Keyser, N. 1998. The geology and geochemistry of the Ventersdorp Supergroup in the area between Vryburg, Ottosdal and Mafikeng. Geol. Surv. S. Afr. Bull. (Pretoria) 122:1-117.

King, S. D., and Anderson, D. L. 1995. An alternative mechanism of flood basalt formation. Earth Planet. Sci. Lett. 136:269-279.

Klein, E. M., and Langmuir, C. H. 1987. Global correlations of ocean ridge basalt chemistry with axial depth and crustal thickness. J. Geophys. Res. 92:8089-8115.

Kröner, A., and Tegtmeyer, A. 1994. Gneiss-greenstone relationships in the Ancient Gneiss Complex of southwestern Swaziland, southern Africa, and implications for early crustal evolution. Precambrian Res. 67: 109-139.

Kusky, T. M., and Kidd, W. S. F. 1992. Remnants of an Archean oceanic plateau, Belingwe greenstone belt, Zimbabwe. Geology 20:43-46.

Lambert, R. St. J. 1976. Archean thermal regimes, crustal and upper mantle temperatures, and a progressive evolutionary model for the Earth. In Windley, B. F., ed. The early history of the Earth. New York, Wiley, p. 363-376.

Larsen, T. B.; Yuen, D. A.; Smedsmo, J. L.; and Malevsky, A. V. 1996. Thermochemical modeling of pulsation tectonics and consequences on lithospheric dynamics. Geophys. Res. Lett. 23:217-220.

Larson, R. L. 1991. Latest pulse of Earth: evidence for a mid-Cretaceous superplume. Geology 19:547-550.

Le Bas, M. J. 2000. IUGS reclassification of the high-Mg and picritic volcanic rocks. J. Petrol. 41:1467-1470.

LeCheminant, A. N., and Heaman, L. M. 1989. Mackenzie igneous events, Canada: Middle Proterozoic hotspot magmatism associated with ocean opening. Earth Planet. Sci. Lett. 96:38-48.
Li, Z. X.; Wang, J.; Li, X. H.; and Kinny, P. D. 1999. The breakup of Rodinia: did it start with a mantle plume beneath South China? Earth Planet. Sci. Lett. 173: 171-181.

Lightfoot, P. C.; Sutcliffe, R. H.; and Doherty, W. 1991. Crustal contamination identified in Keweenawan Osler Group tholeiites, Ontario: a trace element perspective. J. Geol. 99:739-760.

Lowey, G. W.; Sinclair, W. D.; and Hills, L. V. 1986. Additional K-Ar isotopic dates for the Carmacks Group (Upper Cretaceous), west central Yukon (Canada). Can. J. Earth Sci. 23:1857-1859.

Lu, F.; Zhao, L.; Deng, J.; and Zheng, J. 1995. The discussion on the ages of kimberlitic magma activity in the North China Platform. Acta Petrol. Sinica 11: 365-374.

Mahoney, J. J.; Pyle, D. G.; Davies, H. L.; Jones, W. B.; Frey, F. A.; and Salters, V. J. M. 1995. Geochemical characteristics of lavas from Broken Ridge, the Naturaliste Plateau and southernmost Kerguelen Plateau: Cretaceous plateau voclanism in the southeast Indian Ocean. Chem. Geol. 120:315-345.

Mahoney, J. J.; Storey, M.; Duncan, R. A.; Spencer, K. J.; and Pringle, M. 1993. Geochemistry and age of the Ontong Java Plateau. In Pringle, M. S.; Sager, W. W.; and Stein, S., eds. The Mesozoic Pacific: geology, tectonics and volcanism. Washington, D.C., American Geophysical Union, p. 233-261.

Maillet, P. 1982. Quelques notes à propos de la petrologie des volcanites de la chaine centrale, de Vaté à Anatom. In Anonymous, ed. Contribution à l'étude geodynamique du Sud-Ouest Pacifique. Bondy, France, Travaux et Documents, Office de la Recherche Scientifique et Technique Outre-Mer 147:61-78.

Marty, B.; Nivin, V.; Balaganskaya, E.; Zimmerman, J. L.; Tolstikhin, I.; and Kamensky, I. L. 1998. Plumederived rare gases in $380 \mathrm{Ma}$ carbonatites from the Kola region (Russia) and the argon isotopic composition in the deep mantle. Earth Planet. Sci. Lett. 164: 179-192.

Matese, J. J.; Whitman, P. G.; Innanen, K. A.; and Valtonen, M. J. 1996. Why we study the geological record for evidence of the solar oscillation about the galactic midplane. Earth Moon Planets 72:7-12.

McCormick, G. R. 1991. Origin of volcanics in the Tethyan suture zone of Pakistan. In Peters, T., ed. Ophiolite genesis and evolution of the oceanic lithosphere. New York, Kluwer, p. 715-722.

McKenzie, D., and Bickle, M. J. 1988. The volume and composition of melt generated by extension of the lithosphere. J. Petrol. 29:625-679.

McNutt, M. K. 1998. Superswells. Rev. Geophys. 36: 211-244.

Mussett, A. E. $1986 .{ }^{40} \mathrm{Ar}-{ }^{39} \mathrm{Ar}$ step-heating ages of the Tertiary igneous rocks of Mull, Scotland. J. Geol. Soc. 143:887-896.

Napier, W. M. 1998. Galactic periodicity and the geological record. Geol. Soc. Spec. Publ. 140:19-29.

Negi, J. G.; Tiwari, R. K.; and Rao, K. N. N. 1990. "Clean" 
spectral analysis of long-term sea-level changes. Terra Nova 2:138-141.

Nelson, D. O.; Morrison, D. A.; and Phinney, W. C. 1990. Open-system evolution versus source control in basaltic magmas: Matachewan-Hearst dike swarm, Superior Province, Canada. Can. J. Earth Sci. 27:767-783.

Nelson, D. R.; Trendall, A. F.; and Altermann, W. 1999. Chronological correlations between the Pilbara and Kaapvaal cratons. Precambrian Res. 97:165-189.

Nelson, D. R.; Trendall, A. F.; de Laeter, J. R.; Grobler, N. J.; and Fletcher, I. R. 1992. A comparative study of the geochemical and isotopic systematics of Late Archaean flood basalts from the Pilbara and Kaapvaal cratons. Precambrian Res. 54:231-256.

Norman, M. D., and Garcia, M. O. 1999. Primitive magmas and source characteristics of the Hawaiian plume: petrology and geochemistry of shield picrites. Earth Planet. Sci. Lett. 168:27-44.

Nutman, A. P.; Chadwick, B.; Rao, B. K.; and Vasudev, V. N. 1996. SHRIMP U/Pb zircon ages of acid volcanic rocks in the Chitradurga and Sandur groups, and granites adjacent to the Sandur schist belt, Karnataka. J. Geol. Soc. India 47:153-164.

Nutman, A. P.; Fryer, B. J.; and Bridgewater, D. 1989. The early Archaean Nulliak (supracrustal) assemblage, northern Labrador. Can. J. Earth Sci. 26:2159-2168.

Olson, P.; Schubert, G.; and Anderson, C. 1987. Plume formation in the $\mathrm{D}^{\prime \prime}$-layer and the roughness of the core-mantle boundary. Nature 327:409-413.

Ostermann, M.; Scharer, U.; and Deutsch, A. 1996. Impact melt dikes in the Sudbury multi-ring basin (Canada): implications from uranium-lead geochronology on the Fox offset dike. Meteorit. Planet. Sci. 31: 494-501.

Paraskevopoulos, G. M., and Economou, M. I. 1986. Komatiite-type ultramafic lavas from the Agrilia Formation, Othrys ophiolite complex, Greece. Ofioliti 11:293-304.

Park, J. K.; Buchan, K. L.; and Harlan, S. S. 1995. A proposed giant radiating dyke swarm fragmented by the separation of Laurentia and Australia based on paleomagnetism of ca. 780 Ma mafic intrusions in western North America. Earth Planet. Sci. Lett. 132:129-139.

Parrish, R. R. 1989. U-Pb geochronology of the Cape Smith Belt and Sugluk Block, northern Quebec. Geosci. Can. 16:126-129.

Pegram, W. J., and Allegre, C.-J. 1992. Osmium isotopic compositions from oceanic basalts. Earth Planet. Sci. Lett. 111:59-68.

Peng, Z. X., and Mahoney, J. J. 1995. Drillhole lavas from the northwestern Deccan Traps, and the evolution of Reunion hotspot mantle. Earth Planet. Sci. Lett. 134: 169-185.

Puchtel, I. S.; Garbe-Schonberg, C. D.; Samsonov, A. V.; Shchipansky, A. A.; Hofmann, A. W.; and Amelin, Y. V. 1999. Combined mantle plume-island arc model for the formation of the $2.9 \mathrm{Ga}$ Sumozero-Kenozero greenstone belt, SE Baltic Shield: isotope and trace element constraints. Geochim. Cosmochim. Acta 63: 3579-3595.
Puchtel, I. S.; Haase, K. M.; Hofmann, A. W.; Chauvel, C.; Kulikov, V. S.; Garbe-Schönberg, C-D.; and Nemchin, A. A. 1997. Petrology and geochemistry of crustally contaminated komatiitic basalts from the Vetreny Belt, southeastern Baltic Shield: evidence for an early Proterozoic mantle plume beneath rifted Archean continental lithosphere. Geochim. Cosmochim. Acta 61:1205-1222.

Puchtel, I. S.; Kröner, A.; Kulikov, V. S.; Kulikova, V. V.; Garbe-Schönberg, C.-D.; Nemchin, A. A.; Arndt, N. T.; Hofmann, A. W.; and Haase, K. M. 1998a. Petrology of mafic lavas within the Onega Plateau, central Karelia: evidence for $2.0 \mathrm{Ga}$ plume-related continental crustal growth in the Baltic Shield. Contrib. Mineral. Petrol. 130:134-153.

Puchtel, I. S.; Shchipansky, A. A.; Samsonov, A. V.; Hofmann, A. W.; Mezger, K.; and Jochum, K. P. 1998 b. Oceanic plateau model for continental crustal growth in the Archaean: a case study from the Kostomuksha greenstone belt, NW Baltic Shield. Earth Planet. Sci. Lett. 155:57-74.

Rainbird, R. 1993. The sedimentary record of mantle plume uplift preceding eruption of the Neoproterozoic Natkusiak flood basalt. J. Geol. 101:305-318.

Rampino, M. R., and Caldeira, K. 1993. Major episodes of geologic change: correlations, time structure and possible causes. Earth Planet. Sci. Lett. 144:215-227.

Rampino, M. R., and Stothers, R. B. 1984. Geological rhythms and cometary impacts. Science 226: 1427-1431.

Richards, M.; Duncan, R. A.; and Courtillot, V. E. 1989. Flood basalts and hot-spot tracks: plume heads and tails. Science 246:103-107.

Richards, M. A.; Jones, D. L.; Duncan, R. A.; and Depaolo, D. J. 1991. A mantle plume initiation model for the Wrangellia flood basalt and other oceanic plateaus. Science 254:263-267.

Riganti, A., and Wilson, A. H. 1995. Geochemistry of the mafic/ultramafic volcanic associations of the Nondweni greenstone belt, South Africa, and constraints on their petrogenesis. Lithos 34:235-252.

Roach, T. S.; Roeder, P. L.; and Hulbert, L. J. 1998. Composition of chromite in the upper chromite, Muskox layered intrusion, Northwest Territories. Can. Mineral. 36:117-135.

Rogers, G. C. 1982. Oceanic plateaus as meteorite impact signatures. Nature 289:341-342.

Romer, R. L.; Scharer, U.; Wardle, R. J.; and Wilton, D. H. C. 1995. U-Pb age of the Seal Lake Group, Labrador: relationship to Mesoproterozoic extension-related magmatism of Laurasia. Can. J. Earth Sci. 32: 1401-1410.

Rudnick, R. L.; Barth, M.; Horn, I.; and McDonough, W. F. 2000. Rutile-bearing refractory eclogites: missing link between continents and depleted mantle. Science 287:278-281.

Sager, W. W., and Han, H.-C. 1993. Rapid formation of the Shatsky Rise oceanic plateau inferred from its magnetic anomaly. Nature 364:610-613.

Saverikko, M. 1990. Komatiitic explosive volcanism and 
its tectonic setting in Finland, the Fennoscandian (Baltic) Shield. Geol. Soc. Finl. Bull. 62:3-38.

Schiotte, L.; Compston, W.; and Bridgwater, D. 1989. UTh- $\mathrm{Pb}$ ages of single zircons in Archaean supracrustals from Nain Province, Labrador, Canada. Can. J. Earth Sci. 26:2636-2644.

Sclater, J. G.; Jaupart, C.; and Galson, D. 1980. The heat flow through oceanic and continental crust and the heat loss of the Earth. Rev. Geophys. Space Phys. 18: 269-311.

Sharma, M. 1997. Siberian Traps. In Mahoney, J. J., and Coffin, M. F., eds. Large igneous provinces: continental, oceanic and planetary flood volcanism. Geophys. Monogr. 100:273-295.

Sheridan, R. E. 1997. Pulsation tectonics as a control on the dispersal and assembly of supercontinents. J. Geodyn. 23:173-196.

Shoemaker, E. M. 1998. Long-term variations in the impact cratering record on Earth. In Grady, M. M.; Hutchinson, R.; McCall, G. J. H.; and Rothery, D. A., eds. Meteorites: flux with time and impact effects. J. Geol. Soc. Lond. Spec. Publ. 140:7-10.

Simonson, B. M.; Davies, D.; and Hassler, S. W. 2000. Discovery of a layer of probable impact melt spherules in the Late Archaean Jeerinah Formation, Fortescue Group, Western Australia. Aust. J. Earth Sci. 47: 315-325.

Simonson, B. M.; Hassler, S. W.; Davies, D.; Wallace, M.; and Reeves, S. 1998. Iridium anomaly but no shocked quartz from late Archean microkrystite layer: oceanic impact ejecta. Geology 26:195-198.

Smewing, J. D.; Abbotts, I. L.; Dunne, L. A.; and Rex, D. C. 1991. Formation and emplacement ages of the Masirah ophiolite, Sultanate of Oman. Geology 19: 453-456.

Spadea, P.; Espinosa, A.; and Orrego, A. 1989. Picrites occurring within ophiolites from the southwestern Colombian Andes. Ofioliti 14:235-251.

Spadea, P.; Marriner, G. F.; Nivia, A.; Saunders, A. D.; Kerr, A. C.; Tarney, J.; and Kempton, P. D. 1999. Cretaceous picrites and high-Mg basalts from SW Colombia: implications for the mantle plume source of the Caribbean oceanic plateau. Ofioliti 24:167-168.

Sparks, R. S. J. 1986. The role of crustal contamination in magma evolution through geological time. Earth Planet. Sci. Lett. 78:211-223.

Stecher, O. 1998. Fluorine geochemistry in volcanic rock series: examples from Iceland and Jan Mayan. Geochim. Cosmochim. Acta 62:3117-3130.

Steiner, J., and Grillmair, E. 1973. Possible galactic causes for periodic and episodic glaciations. Geol. Soc. Am. Bull. 84:1003-1018.

Stone, M. S., and Stone, W. E. 2000. A crustally contaminated komatiitic dyke-sill-lava complex, Abitibi greenstone belt, Ontario. Precambrian Res. 102:21-46.

Stone, W. E.; Jensen, L. S.; and Church, W. R. 1987. Petrology and geochemistry of an unusual Fe-rich basaltic komatiite from Boston township, northeastern Ontario. Can. J. Earth Sci. 24:2537-2550.

Storey, B. C. 1995. The role of mantle plumes in conti- nental breakup: case histories from Gondwanaland. Nature 377:301-308.

Storey, M.; Kent, R. W.; Saunders, A. D.; Salters, V. J. M.; Hergt, J.; Whitechurch, H.; Sevigny, J. H.; et al. 1992. Lower Cretaceous volcanic rocks on continental margins and their relationship to the Kerguelen Plateau. Proc. Ocean Drilling Proc. Sci. Results 120:33-53.

Storey, M.; Larsen, L. M.; Larsen, H. C.; Duncan, R. A.; and Pederson, A. K. 1998. ${ }^{40} \mathrm{Ar} /{ }^{39} \mathrm{Ar}$ geochronology of the West Greenland Tertiary volcanic province. Earth Planet. Sci. Lett. 160:569-586.

Storey, M; Mahoney, J. J.; Kroenke, L. W.; and Saunders, A. D. 1990. Are oceanic plateaus sites of komatiite formation? Geology 19:376-379.

Storey, M.; Mahoney, J. J.; Saunders, A. D.; Duncan, R. A.; Kelley, S. P.; and Coffin, M. F. 1995. Timing of hot spot-related volcanism and the breakup of Madagascar and India. Science 267:852-855.

Stothers, R. B. 1989. Structure and dating errors in the geologic time scale and periodicity in mass extinctions. Geophys. Res. Lett. 16:119-122.

Struyeva, O. M. 1988. Results of discussions on problems of komatiites in the middle Dneiper region. Geokhimiya i Rudoobrazovaniye 16:47-57.

Tackley, P. J.; Stevenson, D. J.; Glatzmaier, G. A.; and Schubert, G. 1993. Effects of an endothermic phase transition at $670 \mathrm{~km}$ depth in a spherical model of convection in the Earth's mantle. Nature 361: 699-704.

Taylor, S. R., and McLennan, S. M. 1985. The continental crust: its composition and evolution. Oxford, Blackwell, $312 \mathrm{p}$.

Tejada, M. L. G.; Mahoney, J. J.; Duncan, R. A.; and Hawkins, M. P. 1996. Age and geochemistry of basement and alkaline rocks of Mahata and Santa Isabel, Solomon Islands, southern margin of Ontong-Java Plateau. J. Petrol. 37:361-394.

Tiwari, R. K., and Rao, K. N. N. 1998. Correlated variations and periodicity of global $\mathrm{CO}_{2}$, biological mass extinctions and extra-terrestrial bolide impacts over the past 250 million years and possible geodynamic implications. Geofizika 15:103-117.

Turner, S.; Mantovani, M.; Regelous, M.; Kelley, S.; and Hawkesworth, C. 1994. Magmatism and continental break-up in the South Atlantic high precision ${ }^{40} \mathrm{Ar} /$ ${ }^{39} \mathrm{Ar}$ geochronology. Earth Planet. Sci. Lett. 121: 333-348.

Unrug, R. 1997. Rodinia to Gondwana: the geodynamic map of Gondwana supercontinent assembly. Geol. Soc. Am. Today 7:1-5.

van Keken, P. E., and Gable, C. W. 1995. The interaction of a plume with rheological boundary: a comparison between two- and three-dimensional models. J. Geophys. Res. 100:20,291-20,302.

Veizer, J.; Bell, K.; and Jansen, S. 1992. Temporal distribution of carbonatites. Geology 20:1147-1149.

Ventkatesan, T. R.; Kumar, A.; Gopalan, K.; and $\mathrm{Al}^{\prime}$ Mukhamedov, A. I. 1997. ${ }^{40} \mathrm{Ar}-{ }^{39} \mathrm{Ar}$ age of Siberian basaltic volcanism. Chem. Geol. 138:303-310.

Vinnik, L.; Chevrot, S.; and Montagner, J.-P. 1997. Evi- 
dence for a stagnant plume in the transition zone? Geophys. Res. Lett. 24:1007-1010.

Weil, A. B.; Van der Voo, R.; Niocaill, C. M.; and Meert, J. G. 1998. The Proterozoic supercontinent Rodinia: paleomagnetically derived reconstructions for 1100 to 800 Ma. Earth Planet. Sci. Lett. 154:13-24.

White, R. S., and McKenzie, D. 1995. Mantle plumes and flood basalts. J. Geophys. Res. 100:17,543-17,585.

Williams, G. E. 1994. Resonances of the fluid core for a tidally decelerating Earth: cause of increased plume activity and tectonothermal reworking events? Earth Planet. Sci. Lett. 128:155-167.

2000. Geological constraints on the Precambrian history of Earth's rotation and the moon's orbit. Rev. Geophys. 38:37-59.

Wingate, M. T. D. 1998. A palaeomagnetic test of the
Kaapvaal-Pilbara (Vaalbara) connection at $2.78 \mathrm{Ga}$. S. Afr. J. Geol. 101:257-274.

Wingate, M. T. D.; Campbell, I. H.; Compston, W.; and Gibson, G. M. 1998. Ion microprobe U-Pb ages for Neoproterozoic basaltic magmatism in south-central Australia and implications for the breakup of Rodinia. Precambrian Res. 87:135-159.

Winter, H. de la R. 1976. A lithostratigraphic classification of the Ventersdorp succession. Trans. Geol. Soc. S. Afr. 79:31-48.

Yale, L. B., and Carpenter, S. J. 1998. Large igneous provinces and giant dike swarms: proxies for supercontinent cyclicity and mantle convection. Earth Planet. Sci. Lett. 163:109-122.

Ying, J., and Nataf, H.-C. 1998. Detection of mantle plumes in the lower mantle by diffraction tomography: Hawaii. Earth Planet. Sci. Lett. 159:99-115. 